\title{
How Does Increased Private Ownership Affect Financial Leverage, Asset Quality and Profitability of Chinese SOEs?
}

\author{
Lina $\mathrm{Ma}^{1}$ (D) $\cdot$ Fengju Xu ${ }^{1} \cdot$ Iqbal Najaf $^{1} \cdot$ Akther Taslima $^{1}$
}

Received: 8 January 2020 / Accepted: 13 August 2020 / Published online: 4 September 2020

(c) Fudan University 2020

\begin{abstract}
This paper uses the "Chinese ownership reforms in 2013" as a natural experiment to test how increased private ownership affects financial leverage, asset quality and profitability of SOEs (state-owned enterprises). The PSM-DID model is conducted using the panel data of SOEs from 2010 to 2018. Results show that the increased private ownership can decrease financial leverage, while increase asset quality and profitability of SOEs. Specifically, it affects financial leverage negatively in the eastern and the central regions, promotes profitability in the eastern region, and the asset quality in the western region. Besides, the negative effect on financial leverage and positive effect on profitability in the competitive industry is much higher as compared to the monopoly industry. Furthermore, an increase in private ownership enhances asset quality in the monopoly industry more than the competitive industry. The study concludes the positive nexus between increased private ownership and corporate performance of SOEs which provides an insight for the Chinese government to further ownership reforms and for SOEs to improve financial performance.
\end{abstract}

Keywords Chinese ownership reforms · Asset quality · Financial leverage · Profitability $\cdot$ PSM-DID model

\section{Lina Ma}

Malina132@163.com

Fengju Xu

xufju@whut.edu.cn

Iqbal Najaf

najaf_iqbal@live.com

Akther Taslima

limaais.du@yahoo.com

1 School of Management, Wuhan University of Technology, Hubei 430070, Wuhan, China 


\section{Introduction}

In recent years, China has received extensive attention from other countries. Chinese SOEs face multiple tasks of political, administrative, and social stability nature. They are the material and political foundations of China's modernization. However, compared with private firms, SOEs are notorious for their cumbersome administrative systems and hierarchy (Lockett 1988), resulting in poor financial performance and low efficiency. The insider control, loss of state assets, and the tunneling behavior are prominent problems faced by SOEs in China (Reported by Guidelines on deepening the SOEs reform issued by China's State Council). Most of the SOEs are money-losing and some selected industries are sheltered by government bailouts (Bai et al. 2006). The Chinese ownership reforms come into play at the right moment.

The ownership reforms were first proposed in the $1920 \mathrm{~s}$ which proposed the system of innovation that aimed at realizing ownership diversification and high productivity of SOEs. With increased market liberalization in the $1990 \mathrm{~s}$, the competition from private sectors has increased and pressed the local governments to privatize SOEs (Cao et al. 1999; Tian 2001). This privatization has accelerated, since the government approved the restructuring of SOEs in $1990 \mathrm{~s}$. This restructuring later promoted the integration of SOEs and the market economy in China.

Since the Chinese Third Plenary Session of the 16th Central Committee in 2003 proposed the ownership reforms plan, the government has established a supervision system of "managing people, affairs, and capital". The proportion of private ownership was on the rise, since then but the productivity of SOEs was much lower than that of non-SOEs (Hsieh and Song 2015). In 2013, the government re-stated the private ownership capital and established the equally strategic status of state and private ownership economy. It became an important turning point in the course of Chinese ownership reforms, after which the reforms entered a stage of full acceleration.

The Chinese ownership reforms are at the core of China's economic system reforms. On one hand, it is a process of reshaping the interest patterns of the stateowned and private economies which is beneficial for resource allocation efficiency and market competitiveness while improving corporate governance in SOEs (Kang and Kim 2012). On the other hand, these reforms emphasize the increase of private property as an engine of innovative growth. This process furthers the transition of Chinese national economy from quantity to quality. Several researchers agree on the notion of the positive impact of increased private ownership on financial performance (Zinnes et al. 2001; Guo et al. 2008; Megginson et al. 2012). Megginson and Netter (2001) point out that the mixed-ownership structure effectively improves the operating performance of firms.

Despite the significant privatization of state assets in China, there are very few studies regarding its impact on financial performance such as financial leverage, asset quality, and profitability of SOEs. Some authors studied the impact of ownership reforms but only focused on the restructuring of SOEs (Shirley and Lixin 1998; Sun and Tong 2003), and their corporate governance and productivity (Groves et al. 1994; Liu et al. 2015). They unconcern the performance 
of SOEs, especially the changes in financial leverage and asset quality of those firms. Moreover, the existing literature pays little attention to the proportion of private capital in the total capital of SOEs which is crucial for important decision making in these firms.

Chinese Corporation Law requires that in order for a general resolution to be passed, more than half of the present shareholders with voting rights should vote for it. The other resolutions which include amending the company's articles, increasing or decreasing registered capital, mergers, separation, or dissolving the company and changing its form, shall be adopted by over $66.67 \%$ of the voting rights. Meanwhile, the "Guidelines for Articles of Association of Listed Companies" stipulates the control rights of the companies. It states that a special resolution can only be passed if two-thirds or more of the existing shareholders vote in its favor.

From the above discussion, it can be found that the ratio of $33.33 \%$ enables private shareholders to veto a special resolution if they do not accept it. They can impose substantial restrictions on the management of state-owned firms due to the powers conferred on them by Chinese corporate law. Besides, the China Insurance Regulatory Commission revised the administrative methods of shareholdings in 2018, defining controlling shareholders as those with a shareholding ratio of over $33.3 \%$ which adds to the importance of $33.33 \%$ mark for decision making. It is a key inflection point in the transition of decision-making power from form to substance. In SOEs, when the shareholding ratio of private ownership exceeds $33.3 \%$, they can exercise significant control collectively. The private shareholders can participate actively in decision making and resolving critical matters of SOEs. This stimulates them effectively exerting their role of supervision and restriction on state shareholders, thereby balancing the dominant position of state shareholders. Therefore, the $33.33 \%$ mark can be seen as a threshold that makes the ownership reforms meaningful.

Further crossing this threshold can make reforms more meaningful and compelling. To improve the financial and operating efficiency of SOEs, the private ownership of SOEs should continue to increase beyond this threshold, reducing state capital and even complete exit to realize the strategic transfer and reconfiguration. It encourages the development of SOEs with non-public capital holdings. However, empirical analysis of the nexus between ownership reforms and SOEs' performance in China is almost non-existent. Our research fills this gap in the literature by focusing on the impact of increased private ownership on financial leverage, asset quality, and profitability of SOEs in the context of China. It also explores empirically up to what extent the private ownership exceeds $33.3 \%$ as the criterion for SOEs ownership reforms. This study attempts to answer the following research questions:

RQ1: How does the increased private ownership affect financial leverage, asset quality, and profitability of Chinese SOEs?

RQ2: Are there regional differences if any in the ownership reforms' effects? What are the main reasons?

RQ3: Which areas of Chinese state-owned firms can effectively improve asset quality and profitability, and decrease financial leverage? Is it in the monopoly or the competitive industry? 
In a way, this paper is a continuation of early researches on Chinese ownership reforms, but it contributes to solving these questions using the PSM-DID model which helps to mitigate the endogenous issues and estimation bias caused by the ownership reforms. It provides solid firm-level evidence explaining the influence mechanism of Chinese ownership reforms on SOEs and supporting theoretical predictions. Empirical results here show that increased private ownership has a positive influence on asset quality and profitability while negative on financial leverage. The grouping regression is also applied to identify the regional and industrial differences in reforms. In the eastern region, increased private ownership is beneficial to improve asset quality and decrease financial leverage. In the central and western regions, private ownership has a positive effect on asset quality. In different industries, the reforms' impact is varying. These findings have guiding significance for government policy-making.

\section{Review of Related Literature and Hypothesis Development}

\subsection{Increased Private Ownership and Financial Leverage}

The capital heterogeneity theory proposed by Lachmann (1978) proposes that all capital resources are heterogeneous and limited by the environment and scope of application. Its heterogeneity is mainly determined by the owner's capital plan and capital structure arrangements. Compared with private ownership, state ownership has stronger political connections, such as government shareholdings, local government administrative interventions, and government-appointed executives. In light of the fact that the state often serves as an insurance provider for SOEs, it has an essential effect on resource allocation, asset disposal, and mergers and acquisitions (Qian 1995). SOEs may have lower bankruptcy risks, and once they get into financial distress, they can receive bailout packages from administrations easily (Faccio et al. 2006). Therefore, it is more likely for an SOE to get better policy and financial support, valuable connections, and high technology resources (Cao et al. 2016; Wang et al. 2017). Besides, banks in China are often influenced by the governments, the higher the proportion of state ownership, the easier it is for SOEs to obtain bank loans. Such SOEs have little incentives to control debt ratio levels, resulting in higher financial leverage that is more obvious in less developed regions (Liu et al. 2011).

In practice, the debt scale of SOEs has grown rapidly after 2008, and the associated debt risks have attracted widespread attention from all sectors of society. Chinese SOEs have a target leverage level and the adjustment rate that is higher than that of non-SOEs, indicating the aggressive leverage policy for SOEs (Rehman et al. 2017). In recent years, deleveraging has become the top priority of SOEs, and ownership reforms are focused on optimizing the capital structure. The huge debt has to be restructured to make new owners willing to take over it. The extent of privatization of SOEs has re-arranged the ownership structure by introducing private capital and selecting a reasonable debt maturity structure. It has decreased the absolute amount of debts and financial expenses of SOEs (Bai et al. 2009). With 
the increase of private ownership, the asset-liability ratio of non-financial SOEs has decreased from $61.55 \%$ in 2015 to $60.76 \%$ in the first quarter of 2018 . Among these, the communication industry posts a decline of $13.45 \%$. In 2018 , the government issued guidelines like "Opinions on strengthening the constraints on assets and liabilities of SOEs". It is clearly stated that by 2020, the financial leverage of SOEs should be reduced by $2 \%$ based on 2017 levels, and gradually matches the average level of enterprises in the same industry and similar scale. Additionally, there is a natural internal relation between ownership reforms and financial leverage of SOEs which directly affects the distribution of control rights and residual claims (Wei and Varela 2003). These reforms are the main tool to deleverage SOEs. Therefore, H1 is proposed.

H1: The increased private ownership has a positive effect on reducing the financial leverage of Chinese SOEs.

\subsection{Increased Private Ownership and Asset Quality}

The agency problems are common in Chinese SOEs and the increased distance of public (real owners) from agent managers (government-appointed executives) makes this problem severe as there is very little fear of governance control (Ding et al. 2008). The supervision and incentive mechanisms of managers are weak (Laffont and Tirole 1993) and there exists asset tunneling in SOEs, where government empowers certain individuals or organizations in the absence of legitimate reasons.

First, subject to the interest correlation between Chinese government departments and SOEs, the products produced by SOEs are usually those in shortage and the price is determined by the government rather than the market. Because of political goals and social responsibilities, the government departments have the right to decide on major issues like the appointment and dismissal of major organizational posts (Rehman et al. 2017). It often intervenes in the management decisions of SOEs to achieve its political goals (Boycko et al. 1996; Narjess et al. 2013) and the political tasks of SOEs with higher administrative levels will be heavier (Bai et al. 2006). Therefore, the operations of SOEs tend to deviate from market rules and these firms have no incentives to improve efficiency, resulting in the loss of stateowned assets and insider control (Qian 1996). Second, part of government functions and responsibilities are transferred to enterprises as a tool for policy implementation and macroeconomic regulations. Considering that the inconsistent interests of owners and operators, the agency costs are huge. Some operators prefer to sacrifice corporate interests in pursuit of their interests which results in reduced profitability and low efficiency.

The ownership reforms emphasize the mutual development of multiple ownership capitals and establish the supervision system based on capital to revitalize assets inventory. The reforms emphasize the essential attributes of state and private capital, which is, achieving the value increment to improve the allocation efficiency of firm assets and resources. With the privatization of SOEs, the state and private ownership coexist (Bai et al. 2006) which forms a balanced diversified shareholding structure. 
It improves corporate governance (Kang and Kim 2012; Liao et al. 2014; Boateng and Huang 2017) and strengthens the supervision of managers (Gupta 2005).

The combination of state and private ownership plays an important synergetic role by bringing together state support and private innovation into SOEs (Liu et al. 2015). The evaluation of operational efficiency gradually shifts from government departments to shareholders and the market, further promoting the separation of government and corporate functions. Under the new institutional framework, SOEs can make business decisions according to market rules and thereby form the strategic layout of state-owned and private assets. This process effectively improves the overall asset quality of SOEs.

H2: The increased private ownership has a positive impact on the asset quality of Chinese SOEs.

\subsection{Increased Private Ownership and Profitability}

According to the capital heterogeneity theory, different types of capital produce different values in the process of its use (Riordan and Williamson 1985; Grossman and Hart 1986). These value attributes can be described as, economic value, social value, and ecological value. Before ownership reforms, SOEs had a weak sense of investment returns, namely, economic value, but a high sense of social and ecological values. It played an irreplaceable role in the economic growth and social stability of China but at the expense of the financial performance of these firms. On the contrary, private ownership expects higher returns and aims to maximize economic benefits. With an increase of the private ownership in SOEs, an equity balance is achieved that, through the behavior game of state and private ownership, prevents controlling shareholders from making profits through "short-cutting" and making up for shortcomings of external governance system (Attig et al. 2008; Boateng and Huang 2017).

In practice, most of the Chinese SOEs are in key industries or fields associated with the national economy and security. They have long been in a dominant or sometimes monopoly position. Those industries normally have a high entry threshold for private ownership, resulting in a lack of innovation efficiency and motivation of SOEs. Chinese ownership reforms are an important breakthrough in SOEs' reforms, and the restrictions on the entry of private ownership will be relaxed gradually. With the increase of private ownership, these firms take lower political responsibilities that help to realize the economic, social, and ecological values of SOEs. As the ultimate goal of private ownership is seeking maximization of individual economic interests which brings technological innovation and management efficiency, the reforms process further boosts market competition (Cuervo and Villalonga 2000). Privatization has a positive impact on firm value (Maury and Pajuste 2005). Megginson and Netter (2001) also affirm the promotional effect of SOEs' privatization on operating efficiency and profitability of these firms.

In addition, the continuous entry of private capital makes SOEs face more competitive pressure, which accelerates the marketization process. While the improvement in marketization can effectively improve corporate governance structure (Attig 
et al. 2008; Boateng and Huang 2017) which in turn has a positive impact on firm profitability (Aivazian et al. 2005; D’Souza and Megginson 2010). Studying Indonesian firms, Astami et al. (2010) provide empirical evidence that SOEs with private capital perform significantly better than those only owned by the government.

H3: Increased private ownership has a promotional effect on the profitability of Chinese SOEs.

\section{Research Design}

\subsection{Sample and Data}

Keeping in mind the provisions of Chinese Corporate Law, this paper selects SOEs with more than $33.3 \%$ of private ownership as samples showing significant ownership reforms. The private ownership includes shares other than central and provincial governments and their respective ministries. The non-financial SOEs listed in Stock Exchanges from 2010 to 2018 are used as research samples. Given data availability, this paper considers the private shareholding ratio of the top ten shareholders, if more than $33.3 \%$ as SOEs that have experienced the Chinese ownership reforms. This bias may make no difference in the estimation of effects of increased private ownership on financial leverage, asset quality, and profitability of SOEs. That is because, in addition to the top ten shareholders, the shareholding ratio of other shareholders is relatively very low.

The screenings are as follows: remove samples with singularities; remove samples with missing data or time-interval; remove ST (listed companies that are specially handled by Stock Exchanges) and *ST (listed companies that suffer losses for two consecutive years and are warned of delisting risks) samples. If the private shareholding ratio is $33.3 \%$ before 2013 , such samples are excluded, because it is not due to the ownership reforms of 2013 and may affect the empirical result. Finally, 108 SOEs that have undergone the ownership reforms after 2013 are selected as samples in the treatment group, and 414 SOEs that remained un-reformed are selected as samples in the control group.

Except for Hong Kong, Macao, and Taiwan, all the other 31 regions in China are divided into three economic regions, that is the eastern, central, and western regions as proposed by the State Planning Commission of China. The eastern region refers to the prefecture-level cities with the earliest implementation of coastal development policies and a higher level of economic development, including industries before the first vertical line. The central region is the sub-developed region, including industries between the two vertical lines and the western region is the less developed region after the second vertical line. The division of SOEs by number and 31 regions is presented in Fig. 1.

It shows that SOEs are mainly concentrated in the eastern region such as Shanghai, Beijing, Guangdong, and Jiangsu and least in the western region. The eastern region has a relatively open policy environment and economic resources 


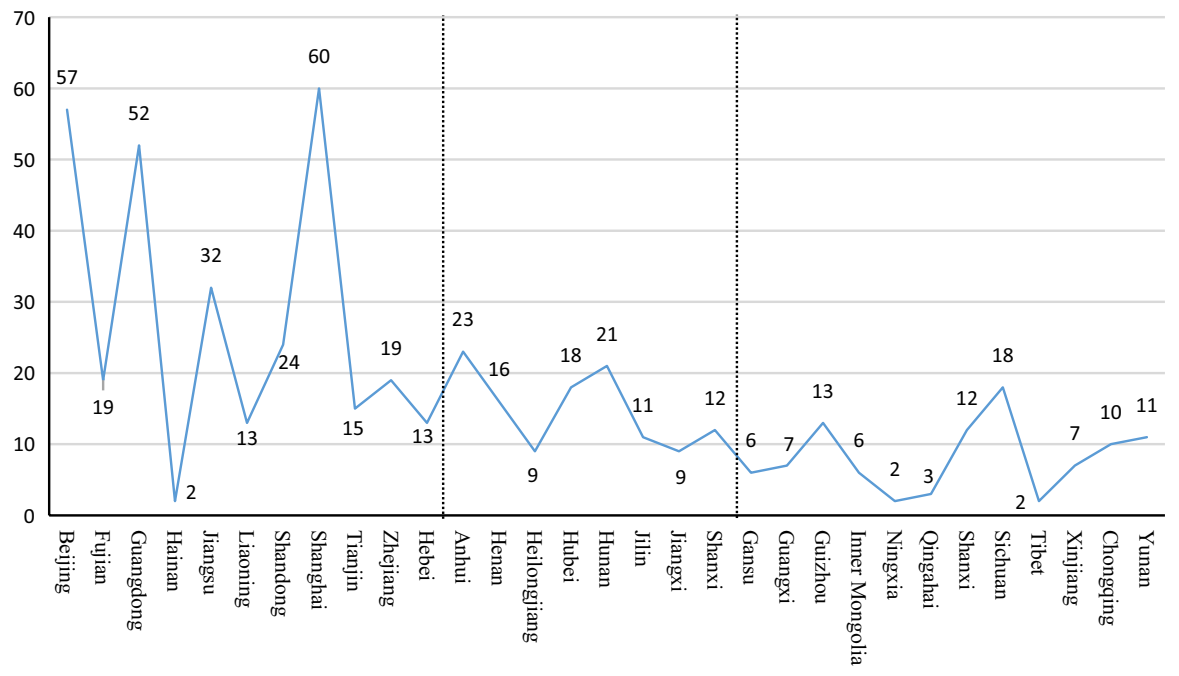

Fig. 1 Distribution by 31 regions and their annual number of SOEs

which provide capital, technology, talents, and other inherent advantages for enterprises. The sample distribution by regions and industries is presented in Table 1.

From Table 1, it is obvious that the distribution of SOEs has regional differences. SOEs are mainly concentrated in the eastern region with a developed economy, accounting for $58.63 \%$ of total and SOEs in the monopoly industries are far more than that in the competitive industries, which suits the law of China's economic development. Market liberalization is higher in the eastern region and it has geographical advantages and resource endowments. Its resource allocation efficiency and production efficiency is much higher in the eastern region. Another important governmental factor like regional policy dividend further promotes resource concentration and more SOEs with monopoly operate in the eastern region.

Table 1 Sample distribution by region and industry

\begin{tabular}{|c|c|c|c|c|c|c|c|}
\hline \multirow[t]{2}{*}{ Region } & \multirow[t]{2}{*}{ Industry } & \multicolumn{2}{|c|}{ Treatment group } & \multicolumn{2}{|c|}{ Control group } & \multicolumn{2}{|c|}{ Total group } \\
\hline & & No. & Percentage & No. & Percentage & No. & Percentage \\
\hline \multirow[t]{2}{*}{ Eastern region } & Monopoly industry & 31 & 28.70 & 138 & 33.33 & 169 & 32.38 \\
\hline & Competitive industry & 28 & 25.93 & 109 & 26.33 & 137 & 26.25 \\
\hline \multirow[t]{2}{*}{ Central region } & Monopoly industry & 14 & 12.96 & 40 & 9.66 & 54 & 10.34 \\
\hline & Competitive industry & 16 & 14.81 & 49 & 11.84 & 65 & 12.45 \\
\hline \multirow[t]{2}{*}{ Western region } & Monopoly industry & 8 & 7.41 & 38 & 9.18 & 46 & 8.81 \\
\hline & Competitive industry & 11 & 10.19 & 40 & 9.66 & 51 & 9.77 \\
\hline Total & & 108 & 100 & 414 & 100 & 522 & 100 \\
\hline
\end{tabular}




\subsection{Methodology}

The study determines the impact of the increased private ownership in SOEs resulting from reforms, on financial leverage, asset quality, and profitability of these firms. The ownership reforms are a nationwide process with gradual progress within SOEs. The announcement of these reforms is essentially an exogenous event, because SOEs are unlikely to restructure their capital by prior knowledge of the country's national reform policies. Due to the exogenous nature of ownership reforms, SOEs that have undergone these reforms are kept in the treatment group and those not implementing these ownership reforms are considered as the control group. This governmental policy provides the basis for this study to use the natural experiment and DID method to estimate the impact of ownership reforms on the financial performance of SOEs.

The DID method is to solve the endogenous problem through double-difference under the assumption that the conditions are satisfied, i.e., the treatment and the control group have the same change trend. The basic idea of using DID in this paper is as follows. First, the ownership reform makes the difference between the same SOE before and after the reform. Second, it makes the difference between the treatment and the control group at the same time. The estimation based on the double-difference formation can effectively control both the influence of other synchronic policies or the external environment and the ex-ante difference between the treatment and the control group. Then it tests the implementation effect of the reform. So the ownership reform in 2013 can be taken as a quasiexperiment and its impacts can be estimated by the DID method.

As there are many unchanging and unobservable differences among enterprises that have undergone the ownership reform and those who have not, it is not suitable to directly select later as the control group. Referring to Heyman et al. (2007), this paper adopts the PSM method to estimate the propensity score P(X) of each SOE. That is, the prediction probability of SOE implementing ownership reform under the given condition of other characteristic variable $\mathrm{X}$. Then match the samples of SOEs with reforms and those without to find the control group with the most similar characteristics before the reform to the treatment group. It provides a guarantee for these two groups to have the same development trend. After that, the difference between the experimental group and the control group is mainly whether the enterprise has undergone the ownership reform. It eliminates the bias of sample selection. PSM-DID can effectively control the influence of non-observed factors including the common impact of ownership reform and individually specific factors that do not change over time. Meanwhile, it compensates for the deficiency that the function must be linear when using the DID method to estimate the conditional expectation of the result variable (Smith and Todd 2005). The PSM-DID method can alleviate endogenous problems.

The group dummy variable is Treat ${ }_{\text {group }}$. The treatment group consists of the firms with reformed ownership structure, while the control group includes unreformed firms (firms with no increase in private ownership to reach $33.33 \%$ of the total). If the private shareholding ratio of an SOE reaches $33.3 \%$ in and after 2013 , this study puts it in the treatment group with the firms having reformed 
ownership represented by Treat $_{\text {group }}=1$, otherwise in the control group represented as Treat group $=0$.

The ownership reform is described by a time dummy variable represented as Time. As the ownership reforms were proposed in 2013, this paper sets the period from 2013 to 2018 equal to Time $=1$ and the period from 2010 to 2012 as Time $=0$. Treat $_{\text {group }} \times$ Time represents the cross term between the group and the time. The basic model used in this paper is as follows:

$$
y_{t}=\beta_{0}+\beta_{1} \text { Treat }_{\text {group }}+\beta_{2} \text { Time }_{t}+\beta_{3} \text { Treat }_{\text {group }} \times \text { Time }_{t}+\beta_{4} \text { Control }_{i t}+\mu_{i t}+\tau_{i t}+\varepsilon_{i t} .
$$

In this model, $y_{t}$ denotes the explained variable including financial leverage, asset quality, and profitability, respectively; Treat ${ }_{\text {group }}$ denotes the group dummy variable; Time denotes the time dummy variable; Control $_{t}$ denotes the relevant control variables; $i$ denotes individual SOE; $t$ denotes the year; $u_{i}$ and $\tau_{t}$ denote the individual and year fixed effect, respectively; $\varepsilon_{t}$ denotes the random interference term.

For SOEs in the treatment group, the performance fluctuations before and after the ownership reforms are represented by the coefficients $\beta_{0}+\beta_{1}$ and $\beta_{0}+\beta_{1}+\beta_{2}+\beta_{3}$, respectively, while the difference is shown by $\operatorname{diff}_{1}=\beta_{2}+\beta_{3}$. On the other hand, for SOEs in the control group, the fluctuations before and after the ownership reforms are represented by the coefficients $\beta_{0}$ and $\beta_{0}+\beta_{2}$, respectively, while the difference is shown by $\operatorname{diff}_{2}=\beta_{2}$. At the same time the difference between these two groups before and after the ownership reforms is represented by DID $=\operatorname{diff}_{1}-\operatorname{diff}_{2}=\beta_{3}$ and the coefficient of the cross term by Treat group $\times$ Time.

\subsection{Variables}

\subsubsection{Explained Variable}

This paper analyzes the policy effects of "Chinese ownership reforms" on financial leverage, asset quality and profitability of SOEs.

Financial leverage reflects the debt risk and solvency of economic subjects which is generally measured by the asset-liability ratio (Fotopoulos and Louri 2004; Karma and Sander 2005). This paper uses the same indicator to measure the financial leverage of SOEs.

The asset quality is difficult to measure completely by only one indicator. This paper selects total asset turnover, net assets cash ratio, return on equity and return on total assets for measuring this variable which reflects the asset liquidity, asset crashworthiness, and asset profitability, respectively. The "entropy method" is utilized to count the weight and then the comprehensive index for asset quality is obtained.

First, the original data is normalized. Assuming that there are $m$ evaluation indicators, $n$ number of SOEs, and the original matrix is $A=\left(\mathrm{a}_{\mathrm{ij}}\right)_{m \times n}$ then $R=\left(r_{\mathrm{ij}}\right)_{m \times n}$ is obtained after normalization:

$$
r_{i j}=\frac{a_{i j}-\min \left(a_{i j}\right)}{\max \left(a_{i j}\right)-\min \left(a_{i j}\right)} .
$$


Second, the entropy value of the $i_{\text {th }}$ index is determined according to the following equation:

$$
h_{i}=-k \sum_{j=1}^{n} f_{i j} \ln f_{i j},
$$

where $f_{i j}=r_{i j} / \sum_{j=1}^{n} r_{i j}$ and $k=1 / \ln n$. When $f_{i j}$ is $0, f_{i j} \ln f_{i j}$ is 0 . Then the weight of the $i_{\text {th }}$ index is obtained:

$$
w_{i}=\frac{1-h_{i}}{m-\sum_{i=1}^{m} h_{i}}\left(0 \leq w_{i} \leq 1, \quad \sum_{i=1}^{m} w_{i}=1\right) .
$$

The entropy weights of the four aspects of asset quality are $0.2252,0.2581$, 0.2586 , and 0.2582 , respectively, and it is calculated by the following equation:

$$
\begin{aligned}
\text { asset quality }= & 0.2252 \text { total asset turnover }+0.2581 \text { net asset cash ratio. } \\
& +0.2586 \text { return on equity }+0.2582 \text { return on total assets }
\end{aligned}
$$

The measurement of corporate profitability includes ROA, ROE, Tobin's Q, return on equity and operating profit rate, etc. Tobin's Q proposed by James Tobin in 1969 addresses the concern that accounting value may be influenced by the firm's accounting policies. It can be used for comparison between different companies and industries and is internationally accepted to measure firm performance (Loderer and Martin 1997; Song et al. 2011; Terjesen et al. 2016). This study follows the convention in the literature and adopts Tobin's Q to measure the profitability of SOEs.

\subsubsection{Explanatory Variable}

According to the DID model, the main explanatory variable is Treat ${ }_{\text {group }} \times$ Time. The key of PSM to eliminate the sample selection bias lies in the matching quality between the experimental and control group. In the DID model of financial leverage as the explained variable, this paper selects the firm size, years of establishment, average wage, the ratio of independent directors, and ratio of fixed assets as explanatory variables in the PSM model. These are also the control variables that influence financial leverage which meets an important criterion for setting the PSM model proposed by Caliendo and Kopeinig (2008).

Similarly, in the model where asset quality is the explained variable, the firm size, years of establishment, average wage, the proportion of independent directors, firm growth, and asset-liability ratio are selected. On the other hand, in the model where profitability is the explained variable, the firm size, years of establishment, average wage, the proportion of independent directors, asset-liability ratio, capital intensity, and current asset ratio are selected. All variables used here are shown in Table 2 with definitions. 


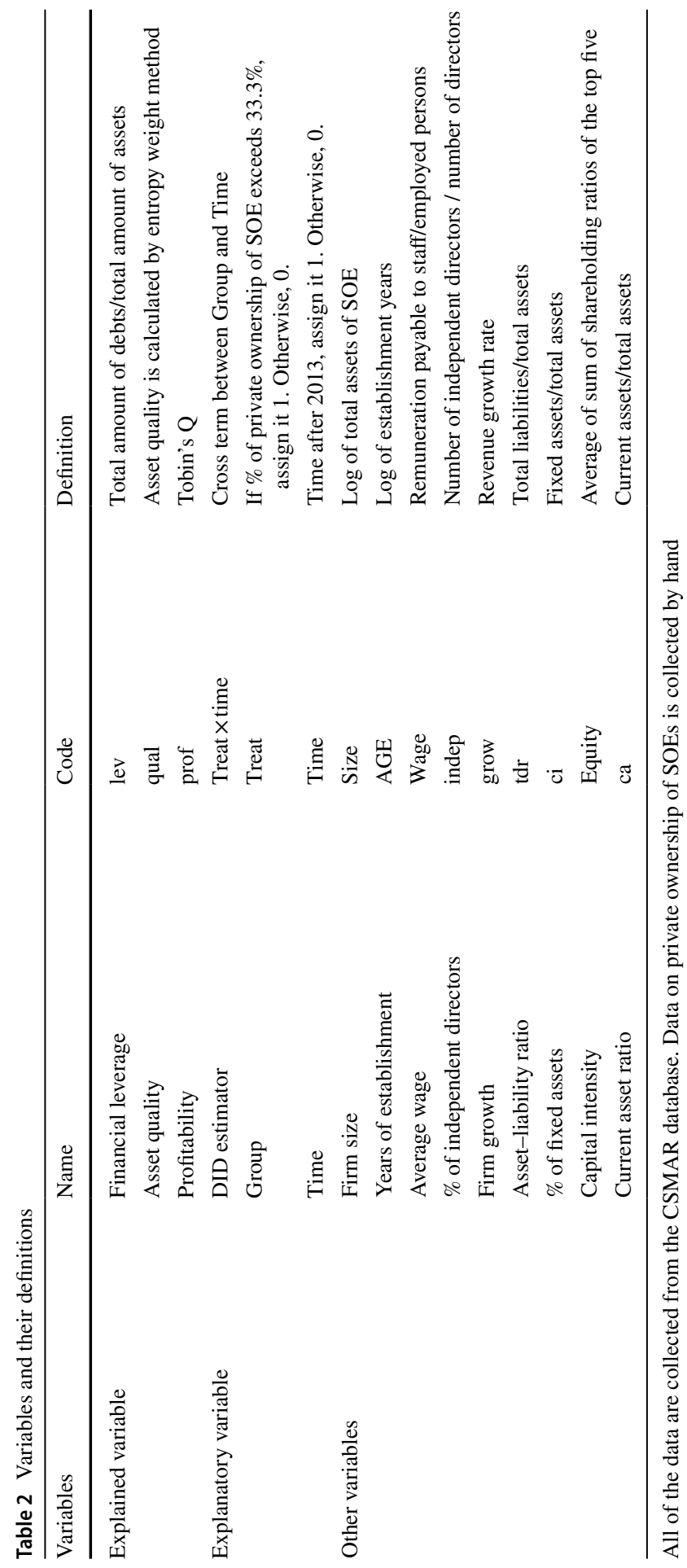




\section{Empirical Analyses}

\subsection{Descriptive Statistics}

Descriptive statistics for each control variable are shown in Table 3. It is clear that the differences in control variables between the experimental group and the control group are not huge, indicating that these two groups are similar. It fulfills the precondition for the DID method.

\subsection{Sample Matching}

Following Heckman et al. (1997), the balance test is used to verify the PSM validity and the results are shown in Tables 4, 5, and 6. As shown in Table 4, compared with unmatched results, the standard deviation of variables is greatly reduced and the absolute values are all less than $10 \%$. It means that matching results balance the data very well. Furthermore, the $t$ statistic after matching is not significant, suggesting that there is little difference between the above two groups. The distribution of variables is relatively balanced. The same results are evident in Tables 5 and 6.

The tables above show the distribution characteristics of the absolute value of deviation before and after PSM. The change of the standardized \% bias before and after the match is shown in Fig. 2a-c. It is clear that the standardized \% bias of most

Table 3 Result of descriptive statistics

\begin{tabular}{llrlllllll}
\hline Group & Variable & \multicolumn{1}{l}{ size } & age & ci & \multicolumn{1}{l}{ grow } & equity & ca & wage & indep \\
\hline Total group & Mean & 22.7839 & 3.2652 & 0.3431 & 0.2191 & 11.0840 & 0.5150 & 9.3776 & 0.3725 \\
$N=4698$ & Std & 1.4222 & 0.1923 & 0.2339 & 1.8970 & 3.3227 & 0.2355 & 1.3135 & 0.0601 \\
& Min & 17.6633 & 2.3979 & 0.0003 & -1 & 0.3060 & 0.0147 & -1.0044 & 0 \\
& Max & 28.5200 & 3.8918 & 0.9709 & 103.812 & 27.9140 & 1.3315 & 15.3960 & 0.8000 \\
& Median & 22.6125 & 3.2958 & 0.3068 & 0.0936 & 11.0470 & 0.5289 & 9.4531 & 0.3333 \\
Treatment & Mean & 22.3931 & 3.2676 & 0.3619 & 0.2001 & 10.0088 & 0.4968 & 9.1721 & 0.3679 \\
group & Std & 1.4026 & 0.2049 & 0.2181 & 1.0022 & 3.3593 & 0.2060 & 1.2195 & 0.0543 \\
$N=558$ & Min & 19.8377 & 2.3979 & 0.0024 & -0.9009 & 1.9440 & 0.0721 & 4.2984 & 0.2500 \\
& Max & 26.7233 & 3.7136 & 0.8919 & 21.8856 & 24.6280 & 1.3315 & 12.0464 & 0.7500 \\
& Median & 22.0920 & 3.2958 & 0.3368 & 0.0901 & 9.8910 & 0.5104 & 9.3711 & 0.3333 \\
Control group & Mean & 22.8365 & 3.2649 & 0.3406 & 0.2216 & 11.2289 & 0.5172 & 9.4053 & 0.3732 \\
$N=4140$ & Std & 1.4168 & 0.1906 & 0.2359 & 1.9871 & 3.2914 & 0.2390 & 1.3233 & 0.0608 \\
& Min & 17.6633 & 2.3979 & 0.0003 & -1 & 0.3060 & 0.0147 & -1.0045 & 0 \\
& Max & 28.5200 & 3.8918 & 0.9709 & 103.812 & 27.9140 & 0.9946 & 15.3960 & 0.8000 \\
& Median & 22.6758 & 3.2958 & 0.2984 & 0.0937 & 11.2120 & 0.5326 & 9.4718 & 0.3333 \\
\hline
\end{tabular}

This table reports the means, Std, minimums, maximums, and medians for all control variables. It is found that the max and min values of individual variables in the total sample, the experimental group, and the control group are similar or identical. That is because the Winsorizing method is applied to the total data before descriptive statistics

$N$ number of observations 
Table 4 Balance test result of the PSM model of deleveraging of SOEs

\begin{tabular}{|c|c|c|c|c|c|c|}
\hline Variable & Mean treated & Mean control & $\%$ bias & $\%$ reduct |bias| & $|t|$ & $\operatorname{Pr}(|T|>|t|)$ \\
\hline \multicolumn{7}{|l|}{ Size } \\
\hline Unmatched & 22.393 & 22.837 & -31.5 & 95.8 & -6.95 & 0.000 \\
\hline Matched & 22.393 & 22.375 & -1.3 & & 0.23 & 0.821 \\
\hline \multicolumn{7}{|l|}{ Age } \\
\hline Unmatched & 3.2676 & 3.2649 & 1.4 & -133.4 & 0.32 & 0.753 \\
\hline Matched & 3.2676 & 3.2740 & -3.2 & & -0.53 & 0.597 \\
\hline \multicolumn{7}{|l|}{ ci } \\
\hline Unmatched & 0.3619 & 0.3406 & 9.4 & 94.0 & 2.02 & 0.043 \\
\hline Matched & 0.3619 & 0.3606 & 0.6 & & 0.09 & 0.925 \\
\hline \multicolumn{7}{|l|}{ Wage } \\
\hline Unmatched & 9.1721 & 9.4053 & -18.3 & 87.1 & -3.94 & 0.000 \\
\hline Matched & 9.1721 & 9.2022 & -2.4 & & -0.41 & 0.685 \\
\hline \multicolumn{7}{|l|}{ ind } \\
\hline Unmatched & 0.3679 & 0.3732 & -9.1 & 33.7 & -1.94 & 0.052 \\
\hline \multicolumn{7}{|l|}{ ep } \\
\hline Matched & 0.3679 & 0.3714 & -6.1 & & -1.06 & 0.290 \\
\hline
\end{tabular}

Variables in the first column are matching variables in the PSM model of the financial leverage of SOEs

Table 5 Balance test result of the PSM model of asset quality of SOEs

\begin{tabular}{lllrcrl}
\hline Variable & Mean treated & Mean control & \%bias & \% Reduct |bias $\mid$ & $|t|$ & $\operatorname{Pr}(|T|>|t|)$ \\
\hline Size & & & & & & \\
$\quad$ Unmatched & 22.393 & 22.837 & -31.5 & 97.2 & -6.95 & 0.000 \\
$\quad$ Matched & 22.393 & 22.381 & 0.9 & & 0.15 & 0.880 \\
Age & & & & & & \\
$\quad$ Unmatched & 3.2676 & 3.2649 & 1.4 & -27.5 & 0.32 & 0.753 \\
$\quad$ Matched & 3.2676 & 3.2711 & -1.8 & & -0.30 & 0.768 \\
c & & & & & & \\
$\quad$ Unmatched & 0.2001 & 0.2216 & -1.4 & -224.9 & -0.25 & 0.801 \\
$\quad$ Matched & 0.2001 & 0.1301 & 4.4 & & 1.56 & 0.118 \\
lev2 & & & & & & \\
$\quad$ Unmatched & 0.4982 & 0.5223 & -12.5 & 47.7 & -2.70 & 0.007 \\
$\quad$ Matched & 0.4982 & 0.4857 & 6.5 & & 1.09 & 0.277 \\
Wage & & & & & & \\
Unmatched & 9.1721 & 9.4053 & -18.3 & 87.2 & -3.94 & 0.000 \\
$\quad$ Matched & 9.1721 & 9.2021 & -2.4 & & -0.39 & 0.695 \\
indep & & & & & -1.94 & 0.052 \\
$\quad$ Unmatched & 0.3679 & 0.3732 & -9.1 & 57.2 & -0.68 & 0.496 \\
Matched & 0.3679 & 0.3702 & -3.9 & &
\end{tabular}

Variables in the first column are matching variables in the PSM model of asset quality of SOEs 
Table 6 Balance test result of the PSM model of profitability of SOEs

\begin{tabular}{|c|c|c|c|c|c|c|}
\hline Variable & Mean treated & Mean control & $\%$ Bias & $\%$ Reduct |bias| & $|t|$ & $\operatorname{Pr}(|T|>|t|)$ \\
\hline \multicolumn{7}{|l|}{ Size } \\
\hline Unmatched & 22.393 & 22.837 & -31.5 & 88.2 & -6.95 & 0.000 \\
\hline Matched & 22.393 & 22.341 & 3.7 & & 0.62 & 0.533 \\
\hline \multicolumn{7}{|l|}{ Age } \\
\hline Unmatched & 3.2676 & 3.2649 & 1.4 & -186.4 & 0.32 & 0.753 \\
\hline Matched & 3.2676 & 3.2598 & 4.0 & & 0.65 & 0.513 \\
\hline \multicolumn{7}{|l|}{ Equity } \\
\hline Unmatched & 10.009 & 11.229 & -36.7 & 93.8 & -8.20 & 0.000 \\
\hline Matched & 10.009 & 10.084 & -2.3 & & -0.38 & 0.705 \\
\hline \multicolumn{7}{|l|}{$\mathrm{ca}$} \\
\hline Unmatched & 0.4969 & 0.5172 & -9.1 & 78.5 & -1.92 & 0.055 \\
\hline Matched & 0.4969 & 0.4925 & 2.0 & & 0.34 & 0.734 \\
\hline \multicolumn{7}{|l|}{ lev2 } \\
\hline Unmatched & 0.4982 & 0.5223 & -12.5 & 54.9 & -2.70 & 0.007 \\
\hline Matched & 0.4982 & 0.4874 & 5.6 & & 0.90 & 0.368 \\
\hline \multicolumn{7}{|l|}{ Wage } \\
\hline Unmatched & 9.1721 & 9.4053 & -18.3 & 55.4 & -3.94 & 0.000 \\
\hline Matched & 9.1721 & 9.2762 & -8.2 & & -1.42 & 0.155 \\
\hline \multicolumn{7}{|l|}{ indep } \\
\hline Unmatched & 0.3679 & 0.3732 & -9.1 & 78.6 & -1.94 & 0.052 \\
\hline Matched & 0.3679 & 0.3690 & -2.0 & & -0.35 & 0.725 \\
\hline
\end{tabular}

Variables in the first column are matching variables in the PSM model of profitability of SOEs

of the variables is reduced after PSM. Therefore, the matched variables and matching method selected in this paper are reasonable and the estimation results of PSM are reliable.

\subsection{DID Test}

Chinese ownership reforms provide an opportunity for a quasi-natural experiment. This paper uses the PSM-DID method to evaluate its effect on financial leverage, asset quality, and profitability of SOEs. The regression results are shown in Table 7.

\section{(1) Increased private ownership and financial leverage}

After controlling for individual and year fixed effects, the coefficient of the DID estimator in the model (1) is -0.0266 and significant at $1 \%$. Consistent with hypothesis $\mathrm{H} 1$, indicating that increased private ownership can reduce the financial leverage of SOEs. The reasons are as follows.

First, the deleveraging of SOEs is an important task for the national economy and a key link for the ownership reforms. With advancing ownership reforms, SOEs absorb more private ownership through market financing, debt-to-equity 

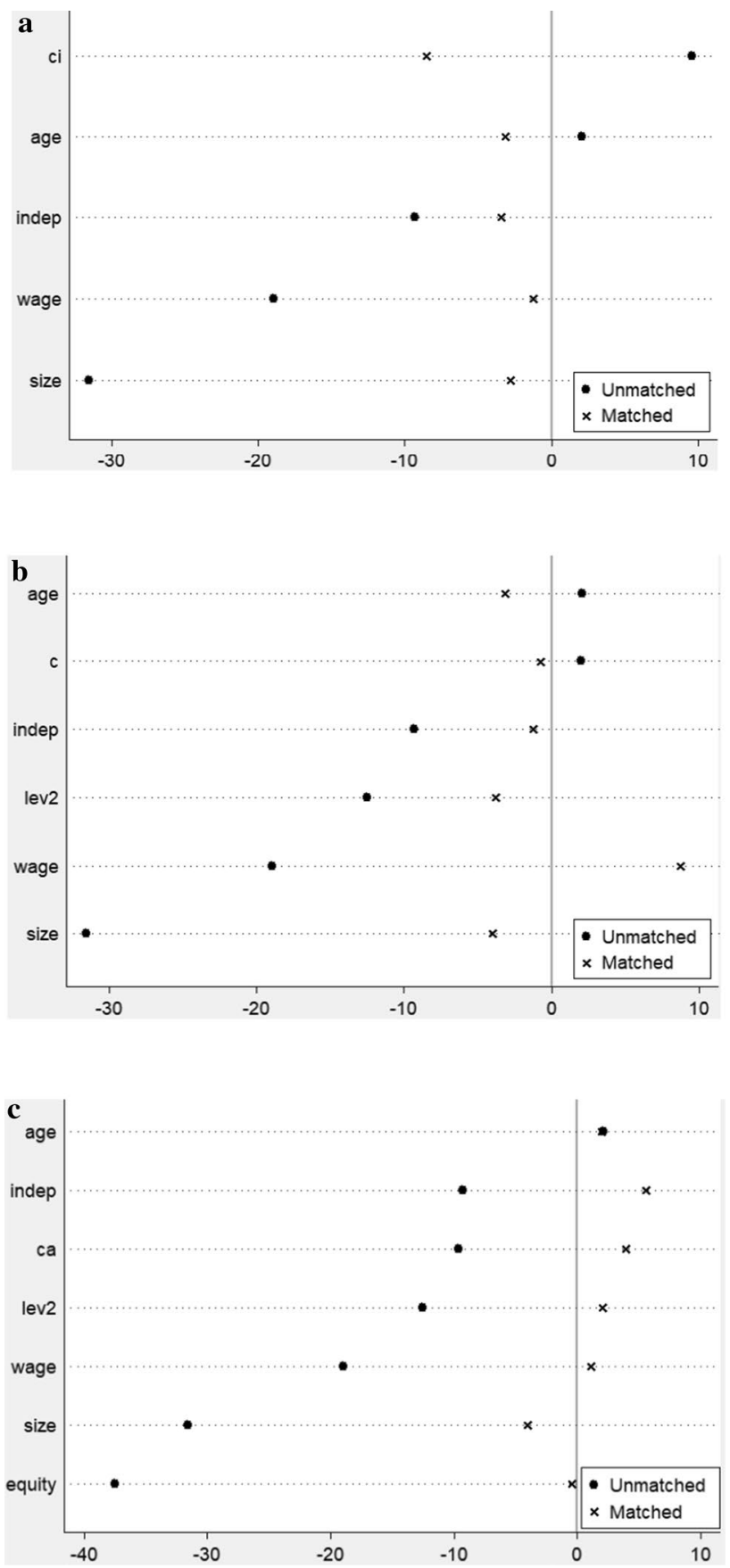

Fig. 2 a Standardized \% bias across covariates of balance test of deleveraging. b Standardized \% bias across covariates of balance test of asset quality. c Standardized \% bias across covariates of balance test of profitability 
Table 7 DID estimation results of the increased private ownership

\begin{tabular}{llll}
\hline Outcome var. & $\begin{array}{l}\text { Model(1) } \\
\text { lev }\end{array}$ & $\begin{array}{l}\text { Model(2) } \\
\text { qual }\end{array}$ & $\begin{array}{l}\text { Model(3) } \\
\text { prof }\end{array}$ \\
\hline Time $\times$ Treat & $-0.0266^{* * *}(-3.56)$ & $0.0000^{*}(1.68)$ & $0.1933 * * *(3.80)$ \\
Treat & $-0.1802^{* *}(-2.38)$ & $0.0001(0.86)$ & $0.1254(0.27)$ \\
Time & $-0.1273^{* * *}(-4.92)$ & $-0.0001^{* * *}(-2.80)$ & $-0.0052(-0.03)$ \\
Size & $0.0770^{* * *}(14.16)$ & $0.0001^{* * *}(6.42)$ & $-0.6201 * * *(-16.04)$ \\
Age & $0.1045(1.30)$ & $0.0002^{*}(1.89)$ & $-0.9912 * *(-1.89)$ \\
Wage & $0.0007(0.31)$ & $-0.0001(-0.54)$ & $-0.0007(-0.06)$ \\
indep & $-0.0017(-0.05)$ & $-0.0000(-0.84)$ & $-0.4282^{* *}(-1.86)$ \\
ci & $0.0504^{* * *(3.19)}$ & & \\
Grow & & $-0.0001 * * *(-10.76)$ & \\
tdr & & $0.0001 * * *(3.25)$ & $-0.074(-0.59)$ \\
Equity & & & $-0.0752(-0.60)$ \\
ca & & & $0.1805(1.29)$ \\
Fm Fix & Yes & Yes & Yes \\
Tm Fix & Yes & Yes & Yes \\
cons & $-1.4840^{* * *}(-4.94)$ & $-0.0037^{* * *}(-8.21)$ & $18.5443 * * *(8.95)$ \\
$N$ & 4698 & 4698 & 4606 \\
$R^{2}$ & 0.8523 & 0.8628 & 0.7414 \\
\hline
\end{tabular}

This table reports the regression coefficients for the effects of the increased private ownership reforms. The value in the parentheses is $t$ statistic

$N$ number of observations, Fm Fix individual fixed effect, Tm fixed year fixed effect

$*$, ** and $* * *$ denote significance at the $10 \%, 5 \%$, and $1 \%$ level

swaps, mergers and reorganizations, and introduction of strategic investors. It becomes conducive to repay the matured debts and reduce the debt burdens of SOEs. Second, the increased private ownership optimizes the capital structure of SOEs and helps to establish the market-oriented operating mechanism, and thereby cleaning up zombie enterprises and zombie assets by reducing the leverage ratio. Furthermore, these ownership reforms have a strong "top-down" driving force. The government sets higher requirements for the construction of selfrestraint and the external-restraint mechanism of the debt leverage. They have also strengthened the financial budget constraints for SOEs. In this way, financial leverage can be reduced greatly.

\section{(2) Increased private ownership and asset quality}

The results from the model (2) show that the coefficient of DID estimator is 0.0000 significant at $10 \%$, indicating that the asset quality of SOEs improves with an increase in private ownership. The hypothesis $\mathrm{H} 2$ is supported by these results. The reasons may be as follows.

First, under the background of the new normal economy in China, the purpose of these ownership reforms is different from the previous ones. It aims at improving the operational efficiency of SOEs and the resource allocation efficiency of 
state-owned capital. By separating high-quality assets and businesses that generate stable cash income for SOEs, it provides a guarantee for sustained profitability of assets. Second, the ownership reforms emphasize the separation of government and enterprise functions and improve the state-owned asset management system. The industrial barriers are gradually broken by absorbing private capital, employee capital, and overseas capital which is beneficial for improving the "asset operation efficiency" of SOEs.

With an increase of private ownership in SOEs, these firms have transformed functional orientation under the guidance of the new national "Two-Step" Strategy. The firms are divided into public SOEs and commercial SOEs according to their core business scope and functions in social development. The former ones aim at improving people's livelihood and the latter at serving the national strategic objectives. This scheme enhances the asset allocation efficiency and lays the foundation for the high-quality development of SOEs. In 2018, the National Development and Reform Commission proposed that measures should be taken to improve the pricing mechanism of state-owned assets, standardize and refine asset evaluation procedures, and asset assessment methods. It has effectively solved the problems of loss and arbitrage of state-owned assets. However, it also needs to be noted that the coefficient is only 0.0000 which is weak from the economic perspective. The improvement of asset management and asset quality of SOEs is a long-term and dynamic process.

\section{(3) Increased private ownership and profitability}

As evident from the results of the model (3), the coefficient of DID estimator is 0.1933 , significant at $1 \%$. These results support the hypothesis $\mathrm{H} 3$.

First, the ownership reforms are at the cross section of multiple types of ownership, integrating advantages of state and private ownership, such as the tax preference advantage, political subsidies for state ownership, operational efficiency, and technological innovation advantage of private ownership. Capitals in different forms of ownership play a synergistic role in business, technology, and management, and enhance the profitability of SOEs. Increased private ownership effectively solves the problem of inefficiency of these enterprises.

Second, before the ownership reforms, the state shareholders were in a dominant position. The opinion of minority shareholders was difficult to be considered while making major decisions. It was hard to restrict the discretion of major shareholders, resulting in insider control, infringement on interests of small and medium-sized shareholders, and even executive corruption which had a negative influence on SOEs' performance. After the ownership reforms, private shareholders in SOEs that have undergone these reforms, have a say in important matters. They can directly participate in decision making now in those SOEs. It is conducive for exerting substantive equity restrictions and reducing the political pressure of government departments on enterprises (Shleifer and Vishny 1994). The supervisory and incentive mechanisms of managers can also be improved significantly (Gupta 2005).

Besides, the results from the model (2) and model (3) show that an increase in private ownership has a positive impact on decreasing financial leverage and increasing asset quality of SOEs. It helps in improving the assets allocation efficiency and 
achieving greater economic benefits as a result. These results are similar to the conclusions of Megginson and Netter (2001).

\subsection{Robustness Test}

Although a lot of control variables are included in this study, it is still impossible to rule out the impact of other factors besides the increased private ownership on financial leverage, asset quality and profitability of SOE. Before going to conclusion, the robustness tests are applied as follows.

\section{(1) Lagging one period of matching variables}

Referring to Girma and Görg (2007), this paper selects 1-year lagged matching variables to perform the robustness test. The results are shown in Table 8 .

Results show that the coefficients of financial leverage and profitability of SOEs are significant at $1 \%$. The coefficient of asset quality is non-significant but still positive. The effect of increased private ownership does not change here substantially.

\section{(2) Placebo test}

The core assumption behind the use of DID model is that there is the same trend of change with the time between the treatment and control group. This paper adopts the placebo test method to demonstrate the applicability of the model by following Bertrand et al. (2004). In samples without the ownership reforms, half of those SOEs are randomly defined as "pseudo-treatment group" and the other half as "pseudo-control group", then the same method is used for empirical analysis. If the coefficient of the DID estimator is not significant, it indicates that the time trend of the same group affected by ownership reforms is unchanged.

As evident from Table 8, the coefficient between pseudo-experimental and pseudo-control groups is not significant, suggesting that the DID model selected in this paper is reasonable and the results are fairly robust.

\section{Regional and Industrial Heterogeneity Tests}

China has a huge and vast territory. Because of the unbalanced regional economic development, resource endowments, and the existence of industrial monopoly protection, the samples of SOEs with different regional and industrial characteristics are grouped and regressed for further analysis.

\subsection{Regional Heterogeneity Test}

The three economic regions in China are used for comparative analysis. The principle of regional division is shown in part 3 and the regional heterogeneity test results are shown in Table 9.

The results show that the effect of the increased private ownership on SOEs is different for different regions.

An increase in private ownership decreases the financial leverage and increases the profitability of SOEs in the eastern region, with the coefficients of -0.0425 


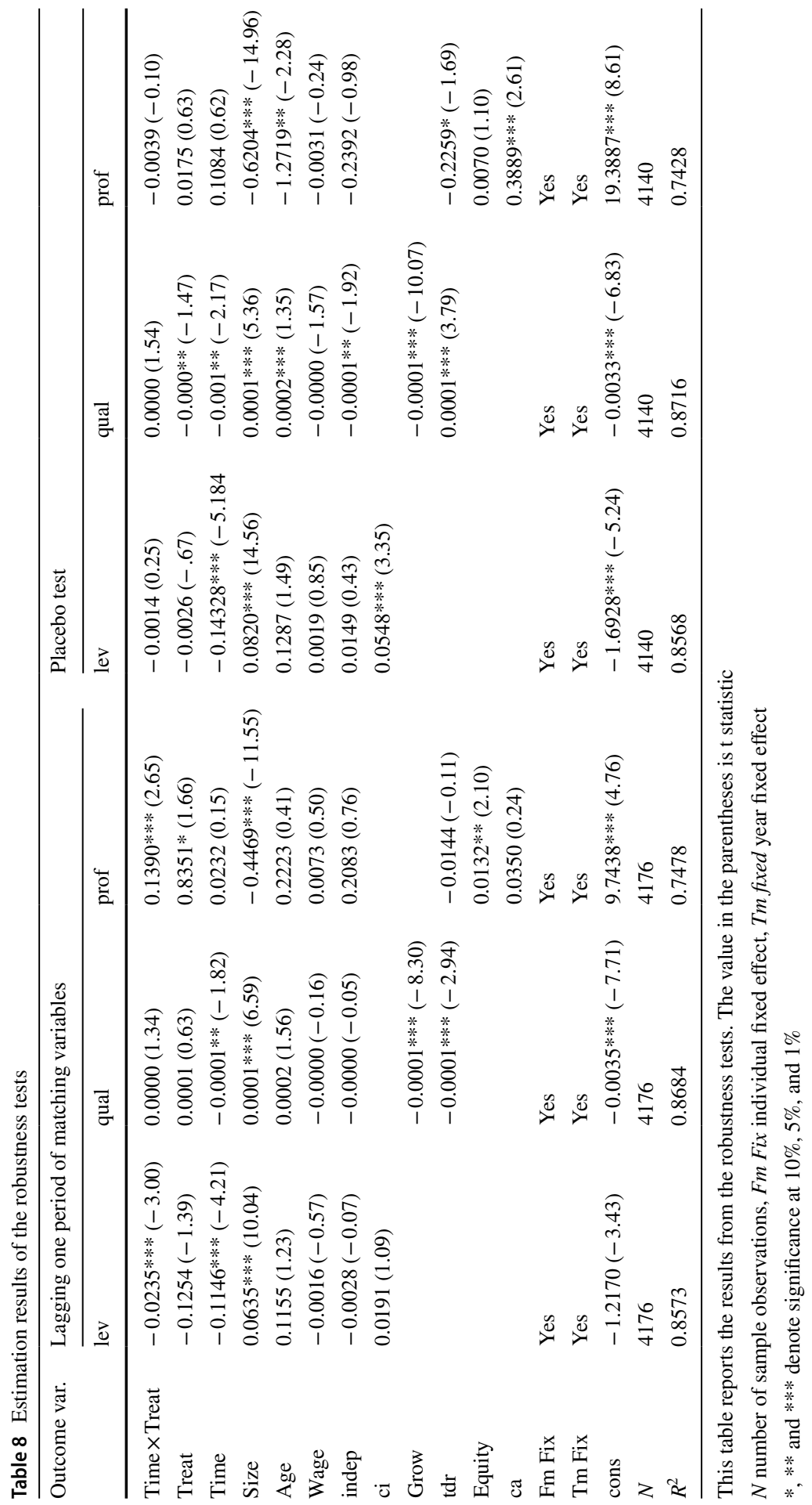




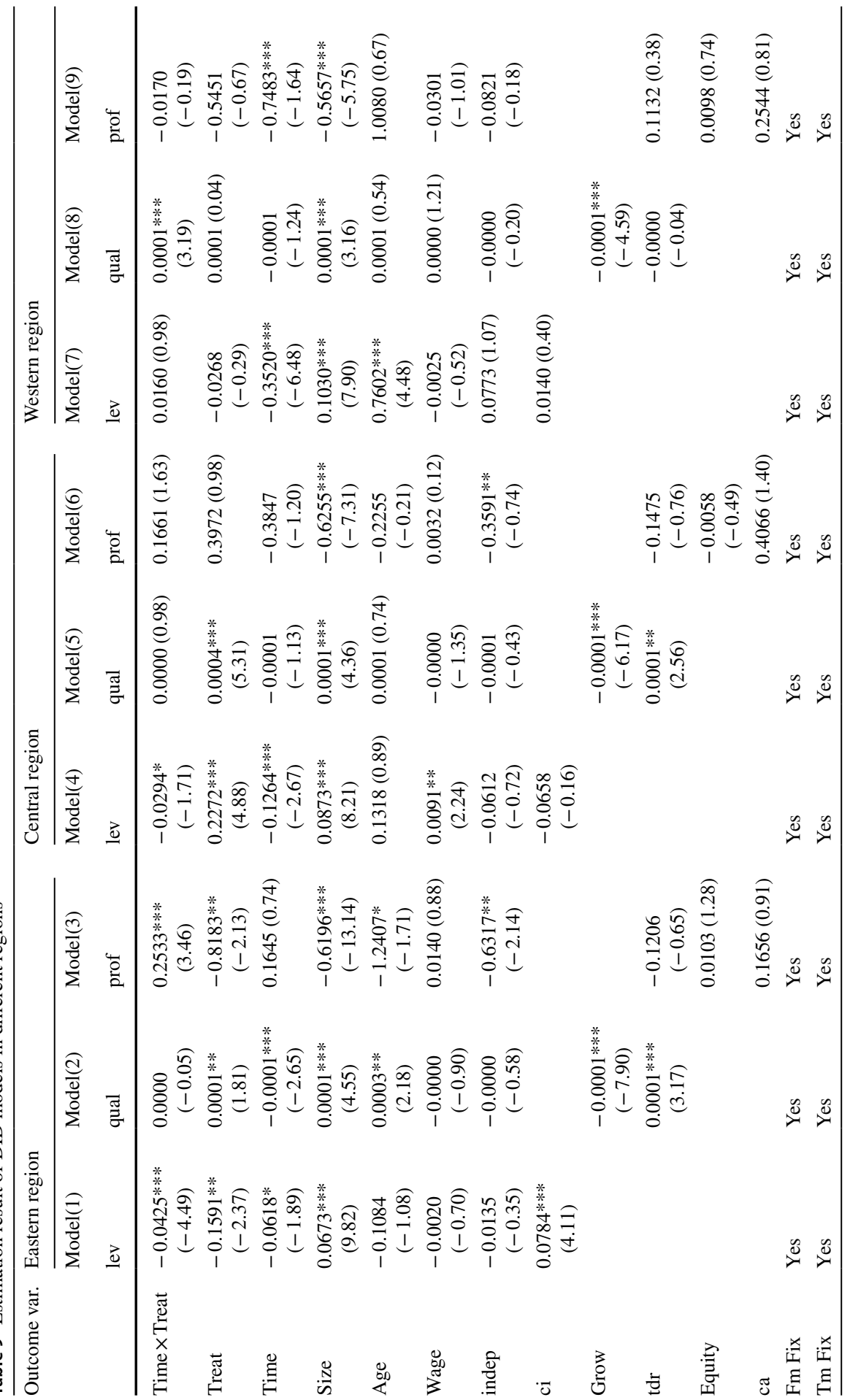




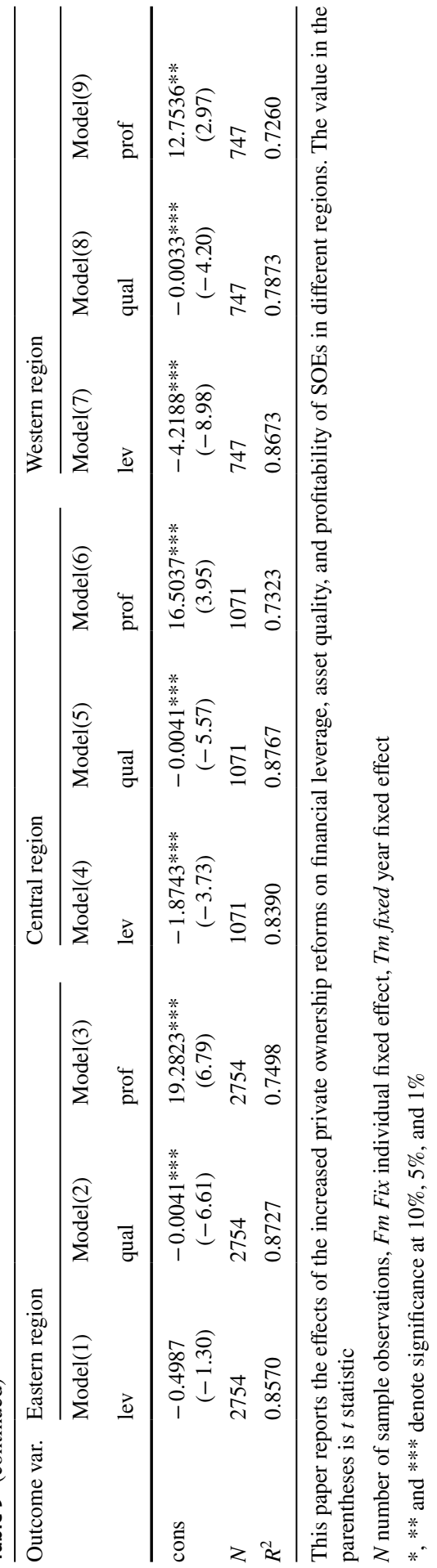


and 0.2533 , both significant at $1 \%$. The reason may be that the important industries and key fields involved in the Chinese national economy are mainly concentrated in SOEs in the eastern region. It is also evident from Table 1 in Sect. 3 showing sample distribution of SOEs, that SOEs are mainly concentrated in the eastern developed areas. The scale of state-owned assets is huge, the economic development and market opening degree are high, and administrative systems are reformed in the eastern areas. All of these features provide the basis for smooth implementation of ownership reforms which has a positive impact on reducing the financial leverage of SOEs. Ownership reforms emphasize capital enlargement and value preservation for stateowned capital to increase the profitability of SOEs. The co-existence of state and private capital in SOEs stimulates their innovation ability and creates a more flexible and efficient market-oriented operational mechanism. It thus improves the business environment in which SOEs operate and affects their profitability positively.

The coefficient of financial leverage for the central region is significant only at the $10 \%$ level and not significant at all in the western region. The increased private ownership has no significant impact on the profitability of SOEs in both of these regions. In fact, the economic foundation of the central and especially the western region is relatively weaker and the administrative reforms are slow. The formulation of policies lacks forward-looking and market awareness is weak. All of these factors aggravate the difficulty in implementing the ownership reforms, so private ownership can hardly be advantageous there. Additionally, the policy effect is influenced by the government's implementation experience and restricted by relevant supporting policies that are relatively backward in the central region, especially in the western region. The eastern region has a sound foundation for ownership reforms and better results comparatively.

The coefficient of asset quality is significant only in the western region, showing that increased private ownership has a positive effect on improving the asset quality of SOEs in western China. Policies like the Great Western Development Strategy, financial investment, tax incentives, and resource development intensity have been continuously supporting the region. It has affected positively, improving the asset quality of SOEs in the western region. However, the coefficients of asset quality in the eastern and central regions are not significant. To some extent, it also indicates that the improvement of asset quality cannot be achieved overnight. The ownership reforms still need to be pushed forward and the current policies should be adjusted timely in response to the problems existing in the process of reforms.

\subsection{Industrial Heterogeneity Test}

To determine the industrial heterogeneity of the impact of increased private ownership on SOEs, firms are divided into the monopoly and competitive industries. Before the regression analysis, the changes in percentage private ownership of SOEs among these two types of industries from 2010 to 2018 are analyzed as shown in Fig. 3.

As a whole, the proportion of private ownership has been on the rise in recent years, from $6.84 \%$ in 2010 to $11.41 \%$ in 2018 for SOEs in the monopoly industry 


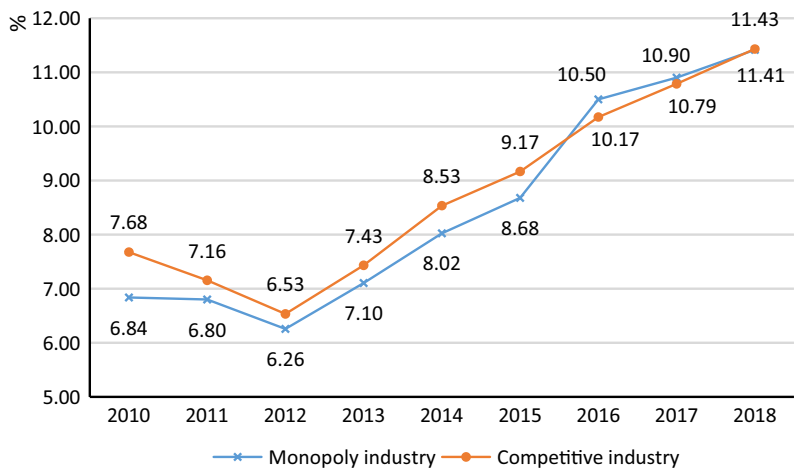

Fig. 3 Changes in percentage private ownership of SOEs in monopoly and competitive industries from 2010 to 2018

and from 7.68 to $11.43 \%$ in the competitive industry. On the contrary, the proportion of state ownership has been declining which confirms the continued convergence of state and private ownership in Chinese SOEs. The estimation results are shown in Table 10.

Table 10 shows that increased private ownership decreases the financial leverage of SOEs with the coefficients of -0.0254 and -0.0278 , respectively, in both monopoly and competitive industries. These coefficients are significant at $5 \%$. It also has a positive impact on profitability with the coefficients of 0.1612 and 0.1997 , respectively, significant at the $5 \%$ and the $1 \%$ level. The absolute values of interaction coefficients in the monopoly industry are less than those in the competitive industry, implying that increased private ownership has a greater impact on the deleveraging and profitability of SOEs in the monopoly industry.

In practice, the ownership reforms move from the monopoly industry towards the competitive industry. The monopoly industry holds higher entry barriers for private ownership, while state ownership is still in the controlling position. These reforms' effect is mainly reflected in the reduced policy burden of SOEs and improved corporate governance structure. In addition to the above effects, the competitive industry is represented by the lower entry barrier and high technological innovation according to market demand. Such industries have higher profitability. The coefficient of the asset quality is positively significant at $10 \%$ in the monopoly industry but not significant in the competitive industry. It reveals that increased private ownership in the monopoly industry has a stronger effect on asset quality as compared with the competitive industry. The reasons may include the relaxation in entry barriers, due to ownership reforms in SOEs of the monopoly industry, as a result, more private capital can enter these firms which stimulates innovation vitality and operational efficiency. This phenomenon is more evident in the monopoly industry. 


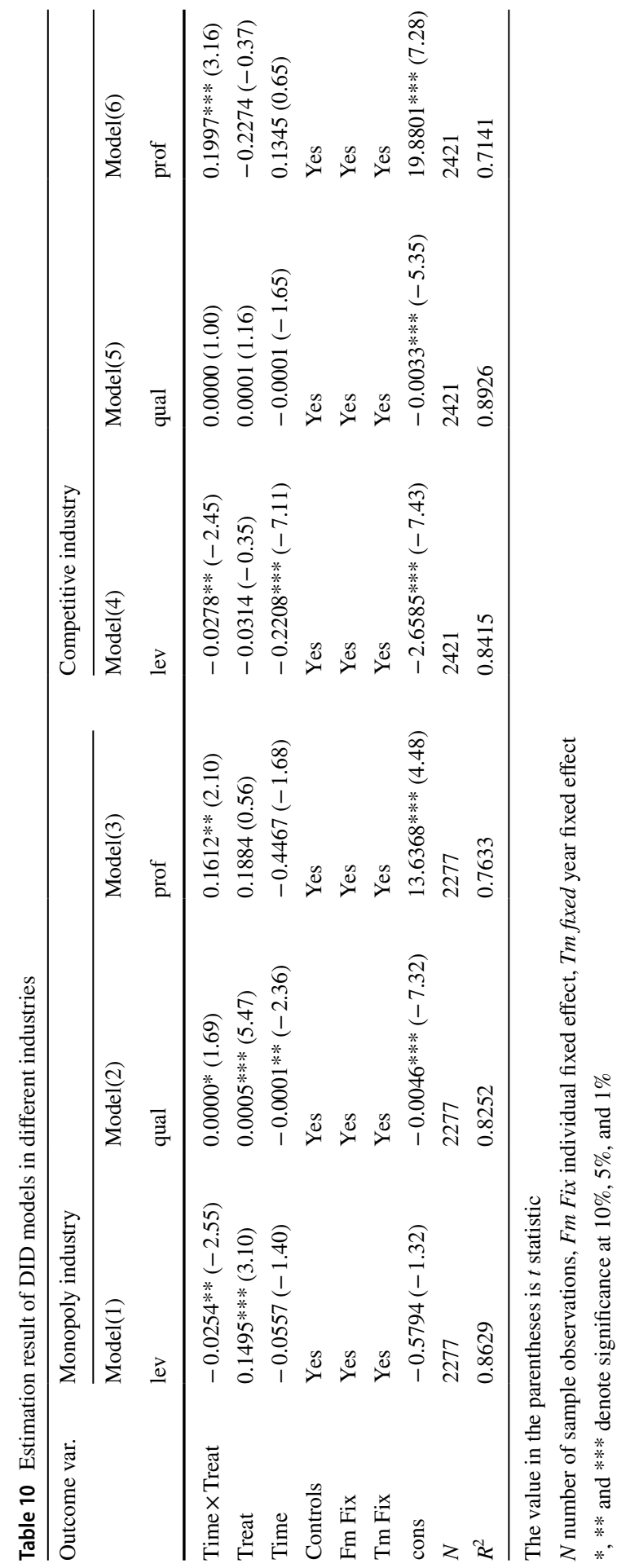




\section{The Influence of the Increased Private Ownership on SOEs Performance in Different Industries}

According to the analysis above, there is heterogeneity in the impact of increased private ownership on monopoly and competitive industries. To further reveal its impact on the corporate performance of SOEs in different industries, the 19 subsectors are divided based on the industry classification standards of the Chinese Securities Regulatory Commission. As the samples in the Health and social work industry and the Resident service, repair, and other services industry are zero from 2010 to 2018, these two industries are removed. Additionally, the Education industry has only 1 sample, whose panel data cannot be regressed. Finally, 15 industries are selected and their codes and the annual number of SOEs are shown in Table 11.

To evaluate the nexus between private ownership and SOEs performance in different industries and to ensure the comparability of the results before and after, Tobin's Q is adopted to measure the SOEs' performance. The following model is constructed for regression based on the panel data of different industries:

$$
\text { performance }_{t}=\alpha_{0}+\alpha_{1} \text { private ownership }_{i t}+\alpha_{2} \operatorname{control}_{i t}+\varepsilon_{i t},
$$

where $i$ is the industry, $t$ is the year, performance is the performance of Chinese SOEs and private ownership is the proportion of private ownership of SOEs. Control means control variables including the firm size, years of establishment, average wage, proportion of independent directors, asset-liability ratio, capital intensity, and current asset ratio. The regression results are shown in Table 12.

The number of observations as represented by $\mathrm{N}$ of the whole industry is 4671 which is different from the previous total of 4698. That is because the regression analysis excludes the industries with a small sample.

As shown in Table 12, the regression results of the entire industry show that the coefficient of the private ownership and performance of SOEs is 0.0100 , significant at $1 \%$. It means that the growth of private ownership has a significant promotional effect on the performance of SOEs which verifies our hypothesis. Further analysis reveals that the positive effect of the private ownership on SOEs performance in the following four industries is more significant; that is Code 3, Code 4, Code 7, and Code 9. The regression coefficients are 0.0141, 0.0082, 0.0079, and 0.0451, respectively, for these industries. Except for Code 7, the coefficients of other industries are significant at $1 \%$. This paper further analyzes the trend in the change of private ownership ratio of SOEs in these four industries. The results are shown in Fig. 4.

As shown in the figure above, the proportion of private ownership is representing a rising trend and fluctuating in more recent years. It increases from $7.27 \%$ in 2010 to $11.39 \%$ in 2018. The proportion of private ownership in Code 9 rises from 8.13 to $22.36 \%$, with a growth rate of $175.74 \%$. Followed by Code 4 with a growth rate of $74.70 \%$, rising from 6.22 to 10.86 . Code 7 has a growth rate of $65.02 \%$, and Code 3 has $47.23 \%$. It is also consistent with the regression results in Table 12 showing that the coefficient of Code 9 is significant at $1 \%$ and the highest at 0.0451 . The lowest value of 0.0141 is in Code 3 . From these results, it is evident that an increase in private ownership in SOEs improves firm performance significantly. 


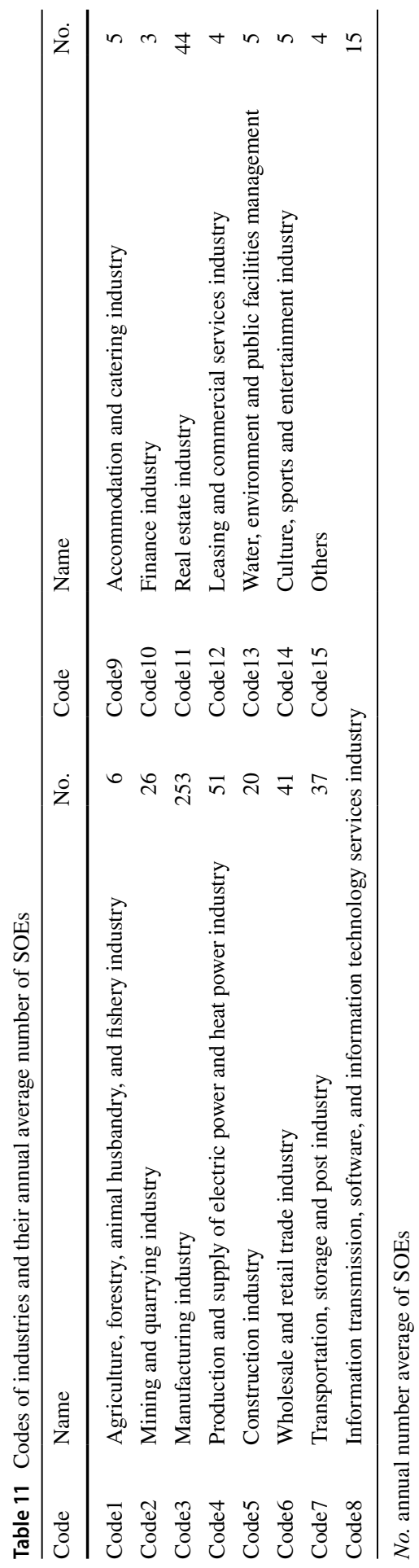




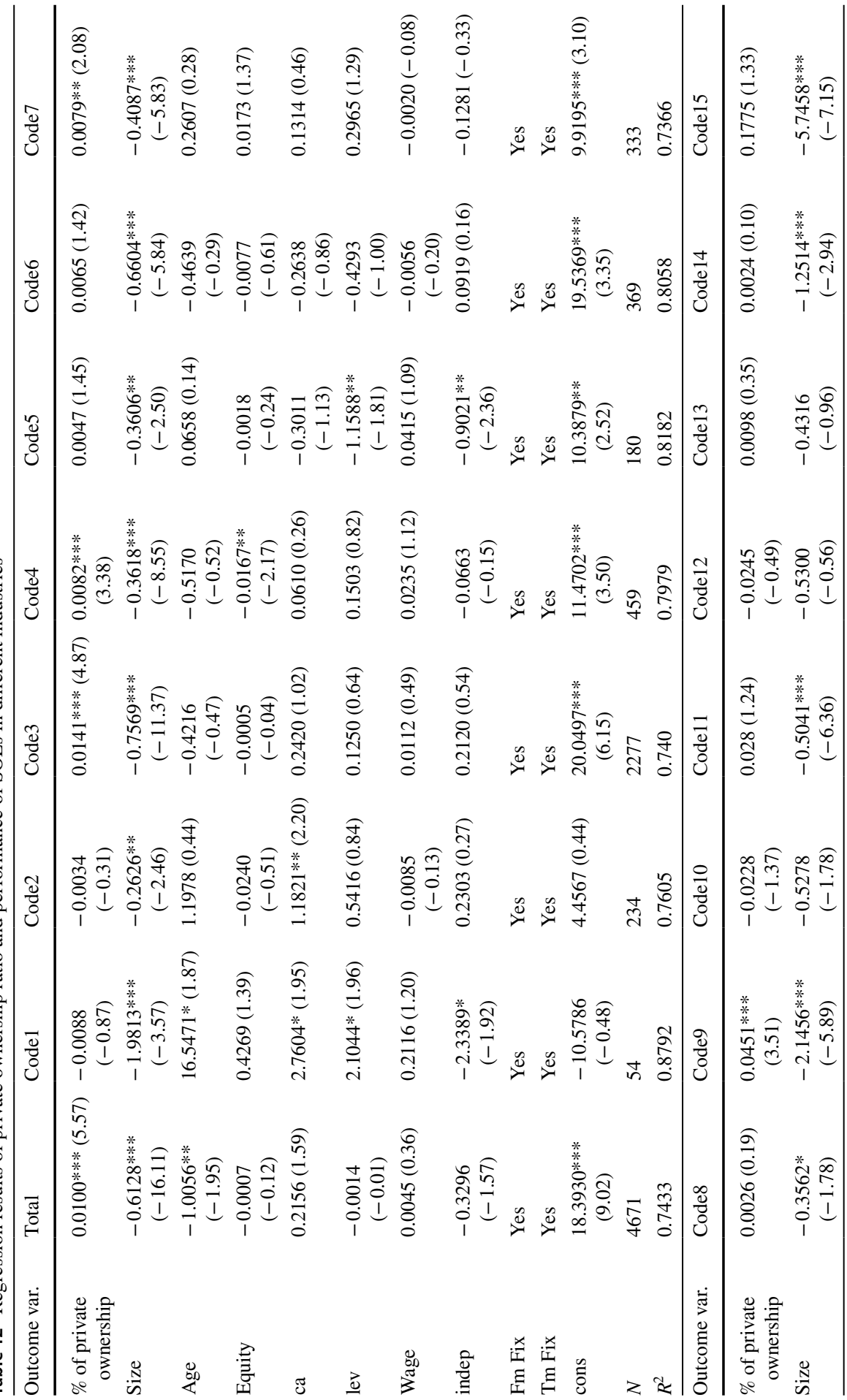




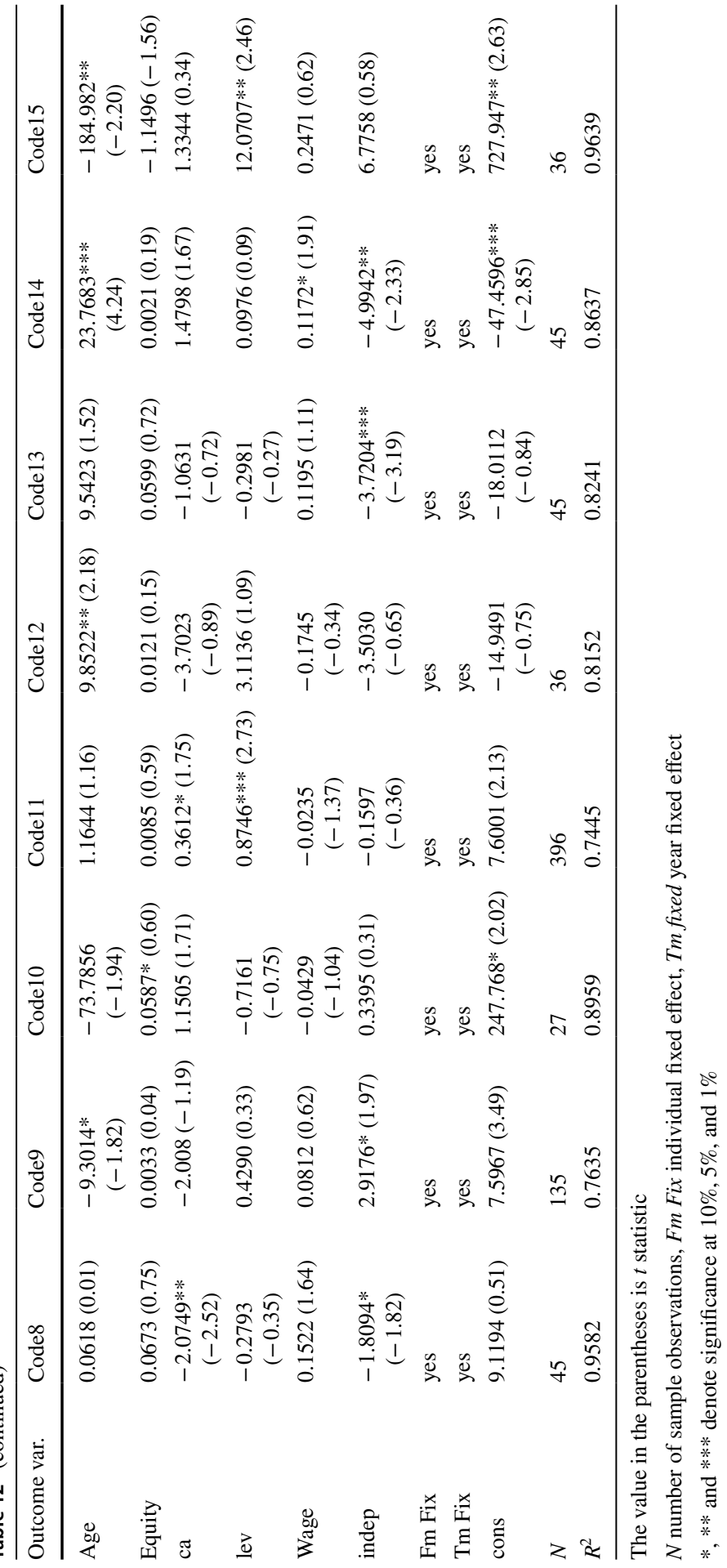




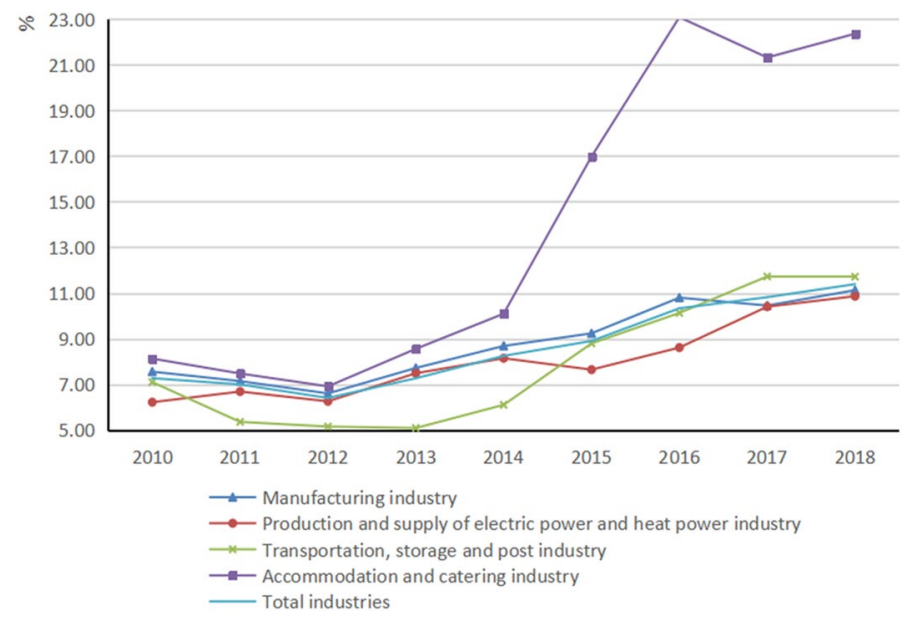

Fig. 4 Trend in change of percentage private ownership of SOEs in the above industries

\section{Implications of the Study, Future Research Direction, and Conclusions}

\subsection{Implications}

As SOEs bear greater political and social responsibilities as compared to non-SOEs, they face more challenges and the ownership reforms are an important breakthrough for these firms' development. Following measures are proposed to be taken for these firms:

First, a differentiating mechanism should between state and private ownership. Only when the ratio of private shareholding reaches the threshold of $33.3 \%$, they can better participate in important decision making and reduce the policy burden on SOEs. At present, the private ownership ratio of most SOEs is still lower than $33.3 \%$. For these enterprises, more private capital should be introduced to improve the powers of private shareholders and transform them into active owners to improve the operational efficiency of SOEs. The development of the Chinese bond market and the transformation to the market economy should be promoted to carry forward the privatization. Meanwhile, it will help to mitigate the agency conflicts in SOEs arising between state and private shareholders and managers.

Second, the integration of state and private ownership can decrease financial leverage and improve asset quality and profitability of SOEs. The state ownership has advantages of tax incentives, political subsidies, and industrial entry barriers, while private ownership has advantages of flexible mechanism, operating efficiency, and fast technological innovation. The focus should be kept on exploiting the comparative advantages of different types of ownership and breaking the soft budget constraints based on the functional orientation of SOEs.

Third, regional and industrial level policies should be made according to the regional and industrial characteristics of SOEs. For SOEs in the central, especially 
the western regions, the small and medium-sized non-state-owned capital is not strong enough to participate in the ownership reforms. The measures proposed include introducing strategic and institutional investors and improvement in the operational mechanism of the property rights trading market to provide a reasonable guarantee for the entry of such investors. Furthermore, it is necessary to analyze the status and role of different industries in economic development and determine the order in which SOEs in different industries should be open to private ownership. Finally, a process of gradual and continuous ownership reforms should be devised in the monopoly industry to elicit the fullest private ownership contribution to Chinese SOEs.

\subsection{Future Research Direction}

This study examines the impact of the increased private ownership on financial leverage, asset quality, and profitability of Chinese SOEs and further analyzes the effect of private ownership on the performance of SOEs in different industries and regions. The ratio of $33.3 \%$ private ownership is used as the threshold to determine which state-owned enterprises have undergone the ownership reforms. However, we propose some directions for future research in this field.

First, due to data availability limitations, we use the sum of the proportion of private ownership of the top ten shareholders as the explanatory variable to determine the level of private ownership in an SOE. In future studies, authors can collect detailed data on shareholding ratios of all non-state-owned shareholders and reanalyze to obtain more precise results.

Second, we divide the 31 regions into only three economic zones which are eastern, central, and western. Future studies can check the impact of the increased private ownership on financial leverage, asset quality, and profitability of SOEs in 31 regions separately to reach more detailed conclusions.

Third, the influencing factors of the increased private ownership of SOEs are not considered in this paper. It can be a good direction for future research work.

\subsection{Conclusions}

Based on the panel data of SOEs from 2010 to 2018, this paper adopts the PSMDID method to explore the effect of increased private ownership on financial leverage, asset quality, and profitability of Chinese SOEs. Firms with private ownership percentage greater than $33.3 \%$ in and after 2013 are considered the ones that have undergone the ownership reforms. The conclusions are as follows.

First, the increased private ownership has indeed played its expected role. It significantly decreases the financial leverage of SOEs and improves the asset quality and profitability of SOEs.

Second, the effects of the increased private ownership on SOEs in different regions are different. It is negatively correlated with the financial leverage of SOEs in the eastern and central regions while positively correlated with the profitability in the eastern region and the asset quality in the western region. 
Third, the effects of the increased private ownership on SOEs have the industrial heterogeneity. It has a stronger impact on decreasing financial leverage and improving the profitability of SOEs in the competitive industry and the stronger positive effect on the asset quality of SOEs in the monopoly industry.

This paper provides empirical evidence on how does the increased private ownership affects financial leverage, asset quality, and profitability of Chinese SOEs. It also reveals the regional and industrial heterogeneity in its effects and confirms the active role of private ownership in SOEs. It should be noted that its effect on asset quality is likely to be a long-term process.

Acknowledgements This work is supported by the China Social Science Foundation (Grant No. 15BJY065) and the International Exchange Project of Independent Innovation of the Wuhan University of Technology (Grant No. 2018-JL-008).

\section{Compliance with ethical standards}

Conflict of interest No conflict of interest is reported by authors.

\section{References}

Aivazian, Varouj A., Ying Ge, and Jiaping Qiu. 2005. Can corporatization improve the performance of state-owned enterprises even without privatization? Journal of Corporate Finance 11 (5): 791-808.

Astami, Emita W., Greg Tower, Rusmin Rusmin, and John Neilson. 2010. The effect of privatisation on performance of state-owned enterprises in Indonesia. Asian Review of Accounting 18 (1): 5-19.

Attig, Najah, Omrane Guedhami, and Dev Mishra. 2008. Multiple large shareholders, control contests, and implied cost of equity. Journal of Corporate Finance 14 (5): 721-737.

Bai, Chong-En, Lu Jiangyong, and Zhigang Tao. 2006. The multitask theory of State enterprise reform: empirical evidence from China. American Economic Review 96 (2): 353-357.

Bai, Chong-En, Lu Jiangyong, and Zhigang Tao. 2009. How does privatization work in China? Journal of Comparative Economics 37 (3): 453-470.

Bertrand, Marianne, Duflo Mullainathan, and Mullainathan Sendhil. 2004. How much should we trust differences-in-differences estimates? The Quarterly Journal of Economics 119 (1): 249-275.

Boateng, Agyenim, and Wei Huang. 2017. Multiple large shareholders, excess leverage and tunneling: evidence from an emerging market. Corporate Governance An International Review 25 (1): 58-74.

Boycko, Maxim, Andrei Shleifer, and Robert W. Vishny. 1996. A theory of privatisation. The Economic Journal 106 (435): 309-319.

Caliendo, Marco, and Sabine Kopeinig. 2008. Some practical guidance for the implementation of propensity score matching. Journal of Economic Surveys 22 (1): 31-72.

Cao, Yuanzhengo, Yingyi Qian, and Barry Weingas. 1999. From federalism, Chinese style to privatization, Chinese style. The Economics of Transition 7 (1): 103-131.

Cao, Xiaping, Douglas J. Cumming, and Sili Zhou. 2016. State ownership and corporate innovation efficiency. Research Collection Lee Kong Chian School of Business.

Cuervo, Alvaro, and Belén Villalonga. 2000. Explaining the variance in the performance effects of privatization. Academy of Management Review 25 (3): 581-590.

Ding, Yuan, Hua Zhang, and Junxi Zhang. 2008. The financial and operating performance of Chinese family-owned listed firms. Management International Review 48 (3): 297-318.

D'Souza, Juliet, and William L. Megginson. 2010. The financial and operating performance of privatized firms during the 1990s. Journal of Finance 54 (4): 1397-1438.

Faccio, Mara, Ronald W. Masulis, and John J. Mcconnell. 2006. Political connections and corporate bailouts. Journal of Finance 61 (6): 2597-2635.

Fotopoulos, Georgios, and Helen Louri. 2004. Firm growth and FDI: are multinationals stimulating local industrial development? Journal of Industry, Competition and Trade 4 (3): 163-189. 
Girma, Sourafel, and Holger Görg. 2007. Evaluating the foreign ownership wage premium using a difference-in-differences matching approach. Journal of International Economics 72 (1): 97-112.

Grossman, Sanford J., and Oliver D. Hart. 1986. The costs and benefits of ownership: a theory of vertical and lateral integration. Journal of Political Economy 94 (4): 691-719.

Groves, Theodore, Yongmiao Hong, John McMillan, and Barry Naughton. 1994. Autonomy and incentives in Chinese state enterprises. Quarterly Journal of Economics 109 (1): 183-209.

Guo, Yan, Jie Gan, and Xu Chenggang. 2008. A nationwide survey of privatized firms in China. Seoul Journal of Economics 21 (2): 311-331.

Gupta, Nandini. 2005. Partial privatization and firm performance. Journal of Finance 60 (2): 987-1015.

Heckman, J.J., I. Hidehiko, and T. Petra. 1997. Matching as an econometric evaluation estimator: evidence from evaluating a job training program. Review of Economic Studies 64 (4): 605-654.

Heyman, Fredrik, Sjoholm FrEdrik, and Tingcall Patrik Gustasson. 2007. Is there really a foreign ownership wage premium? Evidence from matched employer-employee data. Journal of International Economics 73 (2): 355-376.

Hsieh, Changtai, and Zheng Song. 2015. Grasp the large, let go of the small: the transformation of the state sector in China. Brookings Papers on Economic Activity 3391 (1): 295-366.

Kang, Young-Sam, and Byung-Yeon Kim. 2012. Ownership structure and firm performance: evidence from the Chinese corporate reform. China Economic Review 23 (2): 471-481.

Karma, Otto, and Priit Sander. 2005. The impact of financial leverage on risk of equity measured by lossoriented risk measures: an option pricing approach. European Journal of Operational Research 175 (3): 1340-1356.

Lachmann, L.M. 1978. Capital and its structure. Journal of Political Economy 24 (93): 265-266.

Laffont, Jean Jacques, and Jean Tirole. 1993. A theory of incentives in procurement and regulation. Cambridge: The MIT Press.

Liao, Li, Bibo Liu, and Hao Wang. 2014. China's secondary privatization: perspectives from the splitshare structure reform. Journal of Financial Economics 113 (3): 500-518.

Liu, Qigui, Gary Tian, and Xiaoming Wang. 2011. The effect of ownership structure on leverage decision: new evidence from Chinese listed firms. Journal of the Asia Pacific Economy 16 (2): 254-276.

Liu, Guy S., John Beirne, and Pei Sun. 2015. The performance impact of firm ownership transformation in China: mixed ownership vs. fully privatised ownership. Journal of Chinese Economic and Business Studies 15 (3): 197-216.

Lockett, M. 1988. Culture and problems in Chinese management: A preliminary study. American Sociological Review 28: 55-69.

Loderer, Claudio, and Kirkcaldy Martin. 1997. Executive stock ownership and performance tracking faint traces. Journal of Financial Economics 45 (2): 223-255.

Maury, Benjamin, and Anete Pajuste. 2005. Multiple large shareholders and firm value. Journal of Banking \& Finance 29 (7): 1813-1834.

Megginson, W.L., and J.M. Netter. 2001. From state to market: A survey of empirical studies on privatization. Journal of Economic Literature 39 (2): 321-389.

Megginson, William L., Robert C. Nash, and Matthias Van Randenborgh. 2012. The financial and operating performance of newly privatized firms: an international empirical analysis. Journal of Finance 49 (2): 403-452.

Narjess, Boubakri, Jean-Claude Cosset, and Walid Saffar. 2013. The role of state and foreign owners in corporate risk-taking: evidence from privatization. Journal of Financial Economics 108 (3): 641-658.

Qian, Y. 1995. Reforming corporate governance and finance in China. In: Corporate governance in transitional economies: Insider control and the Role of Banks, ed. Aoki M. and Kim H. K. 215-252. Washington, DC: World Bank.

Qian, Yingyi. 1996. Enterprise reform in China: agency problems and political control. Economics of Transition 4 (2): 427-447.

Rehman, Ajid Ur, Man Wang, and Sultan Sikandar Mirza. 2017. How do Chinese firms adjust their financial leverage: an empirical investigation using multiple GMM models. China Finance and Economic Review 5 (1): 1-30.

Riordan, Michael H., and Oliver E. Williamson. 1985. Asset specificity and economic organization. International Journal of Industrial Organization 3 (4): 365-378.

Shirley, Mary M., and Xu Lixin. 1998. Colin information, incentives, and commitment: an empirical analysis of contracts between government and state enterprises. Journal of Law Economics and Organization 14 (2): 358-378. 
Shleifer, Andrei, and Robert W. Vishny. 1994. Politicians and firms. Quarterly Journal of Economics 109 (4): 995-1025.

Smith, Jeffrey A., and P.E. Todd. 2005. Does matching overcome LaLonde's critique of non-experimental estimators? Journal of Econometrics 125 (1-2): 305-353.

Song, Zheng, Kjetil Storesletten, and Zilibotti Fabrizio. 2011. Growing like China. American Economic Review 101 (1): 196-233.

Sun, Q., and W.H. Tong. 2003. China share issue privatization: The extent of its success. Journal of Financial Economic 70 (2): 183-222.

Terjesen, Siri, Eduardo Barbosa Couto, and Paulo Morais Francisco. 2016. Does the presence of independent and female directors impact firm performance? A Multi-Country Study of Board Diversity. Journal of Management and Governance 20 (3): 447-483.

Tian, Guoqiang. 2001. A theory of ownership arrangements and smooth transition to a free market economy. Journal of Institutional and Theoretical Economics 157 (3): 380-412.

Wang, Ruiqi, Fangjun Wang, Xu Luying, and Changhong Yuan. 2017. R\&D expenditures, ultimate ownership and future performance: evidence from China. Journal of Business Research 71 (2): 47-54.

Wei, Zuobao, and Oscar Varela. 2003. State equity ownership and firm market performance: evidence from China's newly privatized firms. Global Finance Journal 14 (1): 65-82.

Zinnes, Clifford, Yair Eilat, and Jeffrey Sachs. 2001. Benchmarking competitiveness in transition economies. Economics of Transition 9 (2): 315-353.

Lina Ma is a Ph.D. at school of management of Wuhan University of Technology, China and a Certified Public Accountant (CPA) in China. She has been a visiting scholar in University of Baltimore. She has recently published in Journals like Journal of Intelligent And Fuzzy Systems, Light and Engineering, and Science of the total Environment. Her main research directions are Financial Markets, Corporate Governance, and Financial Engineering.

Fengju Xu is a professor and doctor tutor of Department of Finance in school of management, Wuhan University of Technology. She is also the standing director of Higher College of Engineer Branch of Accounting Society of China. She has published papers in journals like Journal of Business, Sustainability, and International Journal of Financial Studies. Her research directions are Financial Markets, Corporate Governance, and Internal Control.

Iqbal Najaf is an Associate Professor at College of Economics and Management in Hunan University of Arts and Science, China and a Ph.D. at school of management, Wuhan Universit of Technology. He has professional experience as a banker, insurer and an academician. He has recently published in Journals like Science of the Total Environment, Environmental Research, Air Quality Atmosphere and Health and Journal of Intelligent and Fuzzy Systems. His research interests include "during and post COVID-19 socio-economy", Corporate Finance and Climate Change.

Akther Taslima is an assistant professor of Accounting and Information Systems, Jagannath University. She graduated $\mathrm{PhD}$ from Wuhan University of Technology. She published papers in SSCI, ESCI, SCOPUS, CNKI, Ebscohost indexed and many National and International peer reviewed journals. Her research area includes Auditing, Audit Independence, Audit Quality, Financial reporting, Financial Accounting, Financial Markets, Environment, Technology, Accounting and Auditing, Corporate Governance. 